\title{
Ramón Gaya - Maria Zambrano: Afinidades Electivas
}

\section{Ramón Gaya - María Zambrano: Elective Affinities}

\author{
Pedro Chacón Fuertes \\ Departamento de Filosofía IV \\ Universidad Complutense de Madrid \\ pchacon@filos.ucm.es
}

Recibido: 23 de noviembre de 2010

Aceptado: 24 de noviembre de 2010

\section{Resumen}

Más allá de las coincidencias biográficas entre Ramón Gaya y María Zambrano durante la Guerra Civil y el largo exilio posterior, en los textos de ambos cabe constatar una profunda sintonía y extensas concordancias. En el presente estudio se analizan las raíces existenciales de estas afinidades entre el pintor y la filósofa y la profunda convergencia de sus posiciones ante el arte y la obra creativa. Esta convergencia está basada en una concepción similar de lo real como sagrado. Asimismo, se intenta mostrar los límites de esta convergencia ejemplificándolos en el distinto planteamiento de sus análisis sobre la "verdad simbólica" y la "verdad pictórica" en la obra de Velázquez "El Niño de Vallecas".

Palabras clave: María Zambrano, Ramón Gaya, creación artística, sagrado, verdad pictórica, El Niño de Vallecas.

\begin{abstract}
As well as the biographical coincidences between Ramón Gaya and María Zambrano during the Civil War and the long exile that followed, it is worth mentioning the profound harmony and multiple parallels that exist between the work of both authors. The present study analyses the existential roots of these affinities between the painter and the philosopher, and also the deep convergence of their positions about art and creative work. This convergence is based on a similar con-
\end{abstract}


ception of the "real" as "sacred". The study also tries to show the limits of this convergence as exemplified by the different approach of their analysis of the "symbolic truth" and the "pictorial truth" in Velázquez's work "El Niño de Vallecas" ( The Boy from Vallecas).

Keywords: Zambrano, Gaya, creative work, sacred, pictorial truth, The Boy from Vallecas.

Junto a la felicitación a los organizadores por la iniciativa de celebrar este homenaje a Ramón Gaya, es ineludible que añada mi agradecimiento por haberme invitado a participar en él sin ser un erudito ni un experto en la obra pictórica de Ramón Gaya, ni siquiera un especialista en estética o teoría del arte. Mi aportación sólo se justifica como la de un "buen aficionado", la de alguien que muy recientemente se ha ido acercando a la persona y la obra de Ramón Gaya, sintiéndose, de forma progresiva, seducido por ellas: por la autenticidad e independencia que marcaron su trayectoria vital, y por la coherencia y profundidad de su obra creativa. No tuve la suerte de conocerlo personalmente, como muchos de los que intervienen en este homenaje, pero los sentimientos que en mí ha sabido suscitar su "mano desnuda", desvelando, dejando aparecer en su pintura la verdad de lo real, no han hecho sino acrecentarse cada vez que me encuentro frente a una de sus acuarelas o de sus óleos. Del mismo modo, me he ido identificando con el Gaya pensador, el Gaya que reflexiona sobre la pintura, la suya y la de otros, sobre la pintura de siempre, el caballero andante enemigo de los "ismos" y de los estilos, el Gaya "antimoderno" que nos insta a no recrearnos en los artificios de lo artístico para poder sentir la dimensión creativa de un arte viviente.

Quizá no resulte inútil para el lector que adelante una breve explicación acerca del rótulo y de la intención que presiden el estudio que se dispone a leer. Hace escasos meses tuve la fortuna de encontrar una muy cuidada edición reciente de la obra "Afinidades Electivas" de Goethe en la que su editora y traductora, Helena Cortés, realiza un sugerente análisis de la comunión, de las concordancias y paralelismos, entre la novela del clasicista genio de Weimar y la obra pictórica del romántico Caspar David Friedrich. Las correspondencias entre diferentes concepciones sobre la naturaleza (desde el domesticado jardín ilustrado hasta el salvaje paisaje romántico) y los avatares y estados de ánimo de los personajes habrían encontrado expresiones paralelas en el texto de uno y en los lienzos del otro. De forma similar, a la hora de elegir un tema y un título para mi participación en este homenaje brotó, de forma casi espontánea, el propósito de abordar las "afinidades electivas" entre Ramón Gaya y María Zambrano. En las obras de ambos, en las del pintor y en las de la filósofa, creía haber reconocido una sintonía compartida, una espiritual comu- 
nión, unas similares convicciones, aunque expresadas con distintas modalidades. La tarea parecía estar al alcance de un aficionado como yo y encontraba una justificación complementaria en el hecho de celebrarse este homenaje a Ramón Gaya, el artista contemporáneo español que con mayor claridad y profundidad ha sabido pensar, "filosofar", sobre la pintura, en la casa en la que María Zambrano, la filósofa que con mayor énfasis y clarividencia se ocupó de la poesía y del arte como modos de conocimiento y desvelación de la verdad, se había formado como pensadora, en la casa en la que recibió la influencia directa de sus maestros Ortega y Zubiri, y en la que ejerció de profesora durante un año en sustitución de éste último.

No es preciso rastrear estas afinidades electivas en ningún fondo oculto a la conciencia de los propios protagonistas como en el caso de Goethe y Friedrich cuya profunda coincidencia, en palabras de Helena Cortés, habría sido "involuntaria", y su comunión, perfecta pero "inintencionada". Muy al contrario, la sintonía entre Zambrano y Gaya fue bien consciente y explícita. La admiración mutua que se desborda en los textos en los que uno habla sobre el otro, en los "homenajes" que ambos se tributaron, es fruto de su reconocida comunión de creencias (en el sentido orteguiano del término) y de su "con-cordancia" emocional y afectiva. Su relación personal fue intensa y dilatada en el tiempo pues abarca desde los años treinta hasta comienzos de la década de los noventa. Se moduló y tuvo que adaptarse a las más diversas circunstancias vitales de ambos: hermanados por juveniles esperanzas en una España renovada durante la República, luchando conjuntamente por la independencia del arte y la supervivencia de la cultura, haciendo posible, con el pincel y con la pluma, una revista como "Hora de España" durante la Guerra Civil, sobreviviendo a la dureza del destierro y las dificultades de su integración en México, aprendiendo a convivir con la nostalgia de un retorno, físico y espiritual, a Europa, compartiendo durante años paseos, conversaciones y experiencias en Roma en compañía uno del otro, o de forma epistolar cuando la distancia los separaba, asumiendo, en fin, las vicisitudes de un regreso que pusiera término a su dilatado exilio y las glorias tardías del reconocimiento social en su propio país a unas obras que habían forjado lejos de él y en soledad.

Pero ninguna reduccionista explicación generacional, sociológica o psicologista puede dar cuenta de la hondura y persistencia de las afinidades que encontramos entre María Zambrano y Ramón Gaya. En ocasiones, más bien podría afirmarse que tales afinidades se sostienen y perduran "a pesar de" las diferencias, por ejemplo, de carácter, ideas y formas de vida. Y, por otro lado, ni en uno ni en otro caso, su proximidad o su distanciamiento de otros creadores obedecieron a aquél tipo de razones. Así, María Zambrano se sintió también unida de forma íntima a Lezama Lima, al igual que Ramón Gaya fue siempre un fiel valedor de la poesía y obra de Juan Ramón, por

1 Cortés, H. "La naturaleza romántica: un diálogo entre Goethe y Friedrich" en Goethe, J.W. Las afinidades electivas, La Oficina Ediciones, Madrid, 2010, p.5. 
encima de sus diferencias culturales y generacionales. Más adelante, habremos de volver a preguntarnos sobre la razón de fondo que posibilitó la emergencia, continuidad y profundidad de las "afinidades" entre María Zambrano y Ramón Gaya. Unas afinidades que, apresurémonos a decirlo, no presentan el rostro de ser el fruto de una fortuita elección, de una caprichosa decisión de la voluntad, sino de un destino, si bien en ambos casos se trató de un destino asumido libremente.

La última carta que María Zambrano dirigió a Ramón Gaya la rubricó con firma temblorosa el 11 de octubre de 1990, pocos meses antes de su muerte en febrero de 1991, con ocasión de la inauguración del Museo que se le dedicaba al pintor en su Murcia natal. Le decía entonces: "Ramón, me alegro de veras porque aparezcas en tu tierra, en la finura del mundo, como te dije una vez hace siglos: Murcia es lo más fino que he visto. $Y$ asi nos entendimos "2. O sea, que el entendimiento mutuo debemos retrotraerlo al origen, a la luz a la que se abrieron sus ojos en la infancia y al aire en el que, por vez primera, se le hicieron visibles las cosas. Años antes, en 1976, Ramón Gaya había utilizado idéntico adjetivo al recordar sus visitas al local donde Jorge Guillén y Juan Guerrero editaban "Verso y Prosa" y reconocer en Murcia "una singularidad mucho más imprecisa, más misteriosa, más secreta, más fina (sí, más fina)..." y en su luz tamizada por el polvo "como un leve espesor del aire, como una sutil carnalidad del aire"3. En el caso de María Zambrano, innecesario resulta recordar que siempre se sintió exiliada de su Vélez-Málaga natal, incluso en la Segovia de su adolescencia, aunque la abandonara con apenas cuatro años y no volviera hasta que en ella fuera enterrada. Pero, a mi entender de aficionado, no es en la genérica luminosidad levantina y andaluza de sus raíces donde cabe rastrear el origen, ni el primer testimonio, de sus afinidades. Éste se encuentra, más bien, en la singular y constituyente experiencia de la visión de un niño que abre sus ojos al mundo y queda prendado de la realidad que ve y a partir de la cual conformará su posterior trayectoria vital y estética. En el caso de Ramón, la rama de un níspero; en el de María, la de un limonero.

Sabido es que la infancia de Ramón transcurrió en El Huerto del Conde y que ese paisaje lo marcó hondamente. Ni jardín, ni parque, ni campo ni bosque, el "huerto" murciano es, para Gaya, "una imagen ...poética, esencial, esencializada, de la vida misma"4. Y fue en ese lugar privilegiado donde tuvo lugar la experiencia originaria que permanecería en el fondo de su artística - y me atrevería a decir ontológica- concepción de la realidad. Su propio relato de aquella experiencia es suficientemente explícito para hacer innecesaria y superflua cualquier interpretación teórica: "Siempre que, vuelto hacia mí, reculando en el tiempo, he querido lle-

\footnotetext{
2 Carta inédita de Maria Zambrano a Ramón Gaya. 11 de octubre de 1990. El original se conserva en la Fundación María Zambrano de Vélez-Málaga.

3 Gaya, R. "Merced, 22" en Obra Completa, Valencia, Editorial Pre-Textos, 2010, p. 237

4 Gaya, R. "De los huertos" en Obra Completa (o.c. nota 3), p. 236
} 
gar a lo más antiguo y más escondido de la memoria, a ese primer instante de conciencia animal pura que ha de ser, por lo visto, de donde arranque ya toda nuestra vida, desemboco invariablemente en una imagen muy simple: una rama de nisperero recortándose sobre un cielo azul. Eso es todo". Y continúa preguntándose: “¿Qué hace ahí, en lo profundo, esa rama del árbol sin más ni más?”.

La imagen se mantendrá a lo largo de toda su vida pero la respuesta a su significación se hace esperar más de sesenta y cinco años hasta que Ramón Gaya cree poder "oír" el porqué de esa presencia desnuda de la rama sin sujeto observador y comprender lo que viene a decir tras la superficie de su imagen. La respuesta, formulada existencialmente, constituye una de las más acertadas y luminosas expresiones de su concepción artística de lo real: "Este punto único y solo se encuentra aquí, es aquí, pero se encuentra aquí representando la totalidad del mundo real. Yo no puedo estar dentro, aparecer dentro de esa imagen, porque esa imagen no es una imagen, sino la realidad directa y viviente misma, que ya existe cuando yo todavía no existo (existo ya, sin duda, con dos o tres años, para mis padres, pero no para mí), y antes de tener noticia de mí mismo, conciencia de mí mismo, la realidad parece dar un paso, tenderme la mano para que yo - o mejor, ese garabato del ser que aún no soy-tropiece buenamente con ella y pase, sin sentir, a ser real'"5.

Pocos años antes, una niña en Vélez-Málaga había tenido una vivencia que también cabe calificar de originaria y cuyas similitudes con la que hemos oído narrar a Ramón Gaya son evidentes. También María Zambrano no dejaría de rememorar ese recuerdo infantil como el primero no sólo en el orden temporal sino también en el orden existencial, de su ser-en-el-mundo, y del ser manifestándose de lo real. Acaeció en el patio de su casa (hoy ya inexistente) en la calle Mendrugo y, en lugar de un níspero, fue un limonero el objeto de la visión. En este caso, la imagen no aparece desnuda y aislada, sino que le acompaña la figura paterna, ese ideal del Yo (por decirlo en términos freudianos) que para María Zambrano constituyó su padre, D. Blas Zambrano. Oigámosla rememorando esa experiencia, también muchos años después de haber acontecido, en esa singular autobiografía-novela testimonial de la "generación del toro" que es "Delirio y Destino". "Y aquel otro momento bajo la oblicua luz de la tarde, en lo que debía ser el patio de su casa natal de VélezMálaga, mirando la rama combada muy por encima, con un limón que Él le cortó y le puso en la mano de donde escapó rodando...aquello no era mirada, aunque siempre la sorprendían mirando, pero no era mirada, sino estar pegada, prendida, como si fuese apenas distinta de lo mirado".

Experiencia sentida, vivida, de lo real, como la del nisperero, previa a su ser nombrado y su ser mirado por otro, pues es el propio yo que mira y nombra quien sólo puede constituirse y reconocerse a partir de un desapego y un extrañamiento,

\footnotetext{
5 Gaya, R. "Huerto y vida” en Obra Completa (o.c. nota 3), pp. 232 y 234.
} 
distanciándose de esa experiencia de fusión con lo real que no dejará de intentar recuperar y añorar. En palabras poéticas de María Zambrano, "y el padre la llamaba, la despegaba de aquello y hacía sentir que era distinta, la extrañeza de ser algo". La propia vivencia de verse alzada en brazos hacia lo alto, hacia la rama del limonero, se constituyó en condición de posibilidad de la mirada de la subjetividad hacia la realidad de lo otro: "Y en aquellos viajes del suelo a tan alto, debió de aprender también la distancia, y el estar arriba, ver el suelo desde arriba, mirar desde lo alto la cabeza de su padre, las cosas, las ramas, las paredes se movían, iban cambiando, y eso, atender a lo que cambia, ver el cambio y ver mientras nos movemos, es el comienzo del mirar de verdad; del mirar que es vida"6.

Podría aducirse, en contra de lo que intentamos mostrar, que las afinidades y concordancias entre María Zambrano y Ramón Gaya son evidentes pero que se limitan a ser meras coincidencias resultado de haber compartido, de forma dilatada, tras aquellas originarias experiencias infantiles, muchos retazos de vida y aventuras biográficas. En particular, se subrayará que, en una etapa vital tan decisiva para ambos como la de su juventud, resultaron determinantes los amigos, las esperanzas y los sufrimientos compartidos. Nada habría de extraño, pues, en encontrar en ellos resonancias cuando ambos convivieron y mantuvieron estrecha amistad con personas como, por ejemplo, Luis Cernuda, José Bergamín, Rafael Dieste, Rosa Chacel, Juan Gil-Albert, y Manuel Altolaguirre, formando un grupo de jóvenes intelectuales de la España del primer tercio del siglo XX marcados por la caída de la dictadura del general Primo de Rivera, por la esperanza colectiva que comportó el advenimiento de la Segunda República y, más tarde, por la tragedia de la guerra civil; un grupo de jóvenes intelectuales y artistas que se leían, admiraban y apoyaban mutuamente. Pero esta apreciación, con todo lo que tiene de justa, dejaría en la sombra que, no sólo las relaciones que mantuvieron los miembros de aquél polícromo grupo entonces y en años posteriores, adquirieron muy distintas tonalidades, sino también que las coincidencias entre María Zambrano y Gaya no se dieron siempre en este plano de las relaciones amistosas o grupales.

Así, por ejemplo, por limitarnos a testimonios extraídos de sus años de exilio en Roma, Ramón Gaya en modo alguno comparte la afinidad que María Zambrano mantenía con Diego de Mesa. En carta a Salvador Moreno de 30 de mayo de 1956 llega a decir de él: "éste no pertenece a los inteligentes que dicen tonterías, pero se mueve entre los inteligentes y en casa de María hay que tragarlo y oírlo a todas horas" 7 . Pero, quizá, el testimonio más significativo de las discrepancias estéticas entre María Zambrano y Ramón Gaya lo encontramos líneas más adelante de esta misma carta en relación con el pintor contemporáneo español más admirado por

\footnotetext{
6 Zambrano, M. Delirio y Destino (Los veinte años de una española), Madrid, Mondadori, 1989, p.25

7 Gaya, R. "Carta a Salvador Moreno" 30 de mayo 1956, en Cartas de Ramón Gaya. Murcia. Museo Ramón Gaya, 1993, pp. 51-52.
} 
María: Luis Fernández. Lo había conocido en París y sobre él había escrito un bello ensayo en 1951 en el que llegaba a decir: "Verdad es todo lo que nos ofrecen las telas de Luis Fernández. Esta ascensión de las entrañas a la claridad del alma se ha verificado, a través de un camino perceptible, en una apasionante historia que sus cuadros nos revelan" 8 . Pues bien, esa verdad pictórica no deja de ser, a los ojos de Gaya, un espejismo: "María suspira por París, en donde dice que la gente 'se quema en 'La Pasión!'. Después resulta que por quien verdaderamente suspira es por el pintor Fernández, al que supone algo sagrado. (Me habian hablado de esta pasión de María pero no lo había querido creer hasta que...no tengo más remedio). Es impresionante ver una persona como María, con su talento, es más, con su genio, victima de un espejismo"9. Tampoco, en fin, comparte la positiva valoración que tanto Zambrano como Tomás Segovia tenían de Albert Camus a quien dedica este duro juicio en una carta a su amigo poeta: “....ya no comparto tu admiración por él; le he visto algo chato, de miseria francesa, apañadito, de moralina pobre, incluso trucada (no a la manera grande, gitana, expuesta, sino a la manera disimuladita y burguesa). Su vanidad (sin límites), disimulada cuidadosamente en una salsa contraria, 'mi fa veramente schifo"'10.

Frente a estas y otras explícitas divergencias, son innumerables las ocasiones en las que las coincidencias entre María Zambrano y Ramón Gaya revelan profundas afinidades en su sensibilidad emocional y estética. No me refiero tan solo a las comunes admiraciones hacia poetas y artistas con los que habían convivido y compartido el exilio. Ni siquiera a la coincidencia casi literal que encontramos en los escritos que uno y otra redactaron en aquella época fraticida exponiendo su visión de lo que estaba en juego. Como muy acertada y documentadamente ha mostrado Andrés Trapiello en su obra "Las armas y las letras", las emociones subjetivas y la retórica expresiva de jóvenes pertenecientes a ambos bandos en lucha no dejaban de mostrar grandes similitudes ${ }^{11}$. La esperanza y el idealismo encerrado en la frase con la que Alberto Sánchez tituló su escultura que formaba parte, junto al Guernika de Picasso y dos obras de Gaya, del Pabellón Español en la Exposición de París, "El pueblo español tiene un camino que conduce a una estrella", fueron expresados con ligeras variaciones por muy distintas voces que soñaban con caminos y estrellas muy diferentes. No son estas llamativas genéricas coincidencias las que revelan de forma más significativa la afinidad entre María Zambrano y Ramón Gaya, sino, en todo caso, la compartida actitud de independencia de juicio personal y de defensa

\footnotetext{
8 Zambrano, M. "El misterio de la pintura española en Luis Fernández" en Algunos lugares de la pintura. Madrid, Espasa Calpe, 1989, p.183.

9 Gaya, R. "Carta a Salvador Moreno" 30 de mayo 1956 (o.c. nota 7) pp. 52-53

10 Gaya, R. "Carta a Tomás Segovia" 19 de febrero 1958, en Algunas Cartas, Valencia, Pre-Textos, 1997, p.44

11 Cfr.. Trapiello, A. Las armas y las Letras. Literatura y Guerra Civil (1936-1939), Barcelona, Destino, 2010.
} 
de la dignidad de lo artístico frente mandatos partidistas y criterios emanados de quienes se consideraban la encarnación de la voz popular y de una "verdad histórica", incluso cuando tales partidos y personas luchaban en su mismo lado de la trinchera. Poca duda cabe de la fidelidad que tanto Ramón Gaya como María Zambrano mantuvieron con los ideales republicanos, y de la identificación, en aquellos años, de sus existencias individuales con causas colectivas y populares. Sin embargo, ello no libró a María Zambrano de ser objeto de sospecha por su participación en el proyecto de creación del "Frente Español" en 1932, ni de sus problemas para estabilizarse como docente universitaria en México, del mismo modo que la sinceridad y autenticidad de Ramón Gaya le llevaron a enfrentarse en plena guerra civil al cartelista Renau, a la sazón Director General de Bellas Artes o, lo que era lo mismo, enfrentarse al partido comunista, al igual que le llevarían en México, pocos años más tarde, a sufrir los ataques y el aislamiento promovidos contra él por el todopoderoso Diego Rivera acusándole de antirrevolucionario y enemigo del pueblo mexicano por haberse negado a calificar de auténtico artista al "grabador" José Guadalupe Posada.

Comprometidos ambos social y políticamente, coincidieron, sin embargo, en no dejar de reivindicar la independencia del pensamiento y de la creación artística respecto de lo meramente social y político, su no sometimiento a cánones establecidos desde estos ámbitos. Ni "arte social", ni "arte de lucha", ni "arte colectivo". El ejemplar planteamiento y los criterios editoriales de la revista "Hora de España" que María Zambrano y Ramón Gaya defendieron a ultranza, negándose a reducir lo artístico a mera propaganda, distaban mucho de los que imperaban, por ejemplo, en las páginas de la ortodoxamente disciplinada "Nueva Cultura". En palabras de Ramón Gaya en su "Carta a un Juan" de 1937, "si queremos huir de lo que se ha llamado arte aristocrático, y dificil o burgués inmundo, pienso que, en vez de pedir un arte social y de contenido político, sería necesario pedir un arte verdadero, intenso, emocional, pasional de carne y vida" 12 . Ambos coinciden, igualmente, en subrayar que la soledad es el único lugar donde puede acontecer la labor creadora del escribir de una y del pintar del otro. Un poco más adelante en el mismo texto, Gaya afirma con su habitual contundencia: "No se piensa que la verdadera creación -fijate bien, digo creación- sólo puede surgir de la nada, y la nada únicamente quiere acercársenos cuando nos encontramos absolutamente solos"13. En sintonía armónica con el texto anterior, el precioso ensayo "Por qué se escribe", integrado por María Zambrano, en su "Hacia un Saber sobre el Alma", comienza con estas palabras "Escribir es defender la soledad en que se está: es una acción que sólo brota desde un aislamiento efectivo, pero desde un aislamiento comunicable, en que, precisamente, por la lejanía de toda cosa concreta se hace posible un descu-

12 Gaya, R. "Carta a un Juan” (1937) en Obra Completa (o.c. nota 3) p. 745

13 Ibídem, p. 746 
brimiento de relaciones entre ellas...El escritor defiende su soledad, mostrando lo que en ella y únicamente en ella, encuentra" 14

Resulta innegable que la guerra marcó a ambos, como a tantos otros, con el fracaso y el sufrimiento: no fue solo la amargura de la derrota, la pérdida de las esperanzas, ni la dramática transformación de los sueños en delirios, sino, sobre todo, la herida del dolor más íntimo, el sufrido por aquellos a quienes amamos. Los padres de ambos, de María y de Ramón, habían muerto en Barcelona poco antes del final de la guerra, en el mismo año de 1938. Pero lo peor estaba aún por llegar. En el bombardeo sobre los que huyen al exilio en la estación de Figueres por la aviación de Franco muere la primera mujer de Ramón Gaya, Fe Sanz, con la que se había casado en 1936. Sobrevive al bombardeo su única hija Alicia que es recogida por la mujer de Rafael Dieste que las acompañaba. Posteriormente, Ramón Gaya tiene que dejarla al cuidado de su amigo, el también pintor, Cristóbal Hall mientras él se embarca en el Sinaia para iniciar su exilio en México. No volverá a ver a su hija hasta 1952 en Lisboa, trece años después, y, aunque mantendrán breves encuentros en los años siguientes, la relación paterno-filial nunca se recompondría del todo, como una herida que siguiera abierta, sufriendo ambos la imposibilidad de superar aquella separación.

En el caso de María Zambrano, el dolor que gravitó sobre toda su vida posterior fue el provocado al tener que dejar en París a su madre y a su hermana Araceli mientras ella emigra con su marido también a México y, posteriormente, a Cuba y Puerto Rico. Durante años, María Zambrano vivirá atormentada y culpabilizada por los sufrimientos de ambas en medio de un París ocupado por los nazis. Cuando consiga viajar para encontrarse con ellas en 1946, su madre habrá sido enterrada unos días antes y encontrará a Araceli destrozada, física y anímicamente, por las penurias sufridas y las vejaciones de la Gestapo. Victimas de un destino que no les ahorró sufrimientos y les condenó durante años a la soledad, las obras creativas de María Zambrano y de Ramón Gaya, en filosofía y en pintura, sólo fueron posibles por una compartida tozudez y perseverancia en proseguirlas, a la par que se estableció entre ellos una piadosa solidaridad en el sufrimiento. Mientras María cuida hasta la extenuación de su hermana Araceli enferma en Roma, Ramón la acompaña. "Aqui hay, ahora, muchas cosas que no he visto (escribe en la misma carta a Tomás Segovia), porque hace dos meses que la hermana de María Zambrano está en cama, y voy a su casa, exactamente, a la hora en que podría ir al teatro, pues salgo con María a cenar por allí cerca; es lo único que puedo hacer por ellas, y las veo tan agobiadas que no puedo regatearle a María esas dos o tres horas, las únicas que tiene la pobre de...volver en si'. 15

14 Zambrano, M. (1950) "Por qué se escribe" en Hacia un saber sobre el alma. Madrid, Alianza Editorial, 2000, p.35. Un espléndido análisis de las relaciones entre escritura y soledad en Maria Zambrano ha sido realizado por Miguel Morey en su ensayo La visión más transparente.

15 Gaya, R. "Carta a Tomás Segovia" 19 de febrero 1958, en Algunas Cartas (o.c. nota 10), p.42 
En medio de las enfáticas, apasionadas y juveniles apelaciones a una esperanzada "renovación" de España que compartieron con muchos miembros de su generación, cabe también encontrar una profunda afinidad entre Zambrano y Ramón Gaya en la forma como vinculan esa renovación con la tradición y el pasado, con la recuperación como algo vivo de un ser español, que habría sido representado modélicamente por sus escritores. Al respecto, resultan muy significativas la compartida admiración que ambos sienten por el "realista" Galdós y la concordancia en los juicios que emiten sobre sus retratos novelados de la vida española. Coincidencia tanto más relevante cuanto la valoración positiva de Galdós resultaba una excepción en el grupo de intelectuales al que pertenecían muy proclive a minusvalorarlo siguiendo el descrédito en que lo había sumido la generación del 98 y el calificativo de "el garbancero" que le otorgara Valle-Inclán. Un ejemplo más de la antimodernidad y excontemporaneidad de las posiciones estéticas compartidas por ambos. María Zambrano había leído a Galdós con avidez en su juventud aprovechando la biblioteca paterna y sus largos periodos de convalecencia. Al él le consagrará un libro publicado en la editorial Taurus en el año 1960 que fue reeditado y ampliado con posterioridad. La edición de 1989 en La Gaya Ciencia está enriquecida con ilustraciones del propio Ramón Gaya. De la importancia e interés que la obra de Galdós tuvo para María Zambrano es buena muestra el hecho de que su primer estudio sobre él, "Misericordia", date de 1938 (publicado en "Hora de España") y el último sea de 1988, es decir, cincuenta años más tarde.

En su "Delirio y Destino" María Zambrano califica a Galdós de "enumerador de la España sub-histórica, de las entrañas que quedan bajo el vivir histórico, de la vida cotidiana y aún de la historia misma" 16 , y reitera este juicio en otros lugares para encomiar su retrato del pasado de España, de "la grandeza de una España remota reducida a delirio". Pero, con ello, no estaría sino repitiendo un tópico consagrado sobre el autor de "Los Episodios Nacionales". Mayor originalidad y parentesco con las apreciaciones de Gaya, como si ambas respondieran a un mismo sentir ante las novelas galdosianas, es su juicio de que Galdós desciende en ellas hasta una vida oculta, tras la vida "histórica", para, guiado por un afán de conocimiento, detenerse en ella hasta descubrir el secreto de su íntima estructura, "analizando su misterio hasta el límite en que todo misterio consiente en ser desvelado por una luz ajena"17. Esta apreciación del "realista" Galdós como "desvelador" de la verdad de la vida nos lleva de la mano a la reivindicación, zambraniana y gayesca, del realismo español como una forma de conocimiento de la que se habría nutrido toda nuestra cultura y enfrentada, como la razón poética, al anquilosador racionalismo. En palabras de María Zambrano, "a la luz de su aparición, el realismo español será

16 Zambrano, M. Delirio y Destino (o.c. nota 6), p. 66.

17 Zambrano, M. "Misericordia", en Los intelectuales en el drama de España. Ensayos y Notas (19361939). Madrid, Hispamerca, 1977, p. 132 
algo mucho más que una cualidad y más decisivo que un estilo: será simplemente la actuación de este género de saber en el clima hostil de una cultura de origen racionalista que va agotando su ciclo"18. Igualmente significativo y relevante es el hecho de que la condición de posibilidad de este mostrarse de la realidad ante el novelista, al igual que para el pintor, no pase por una actitud avasalladora que intente captarla mediante una técnica, un estilo, un método, o apresarla en una red de ideas, sino sólo a través de un humilde apego y amor a la realidad misma: "La realidad viene así a entregarse plenamente a quien asi se le entrega, y de ahi la riqueza infinita, la infinita complejidad de la novela galdosiana, la magia que de ella emana, más allá de la literatura"19. En la verdadera obra de creación, le oiremos decir a Gaya, a diferencia de la obra artística, al fruto del artificio, la verdad de lo real no es conquistada ni atrapada por el autor, es la propia realidad la que se le entrega cuando el artista está en disposición para ello.

Ramón Gaya dedicó a Galdós un texto, y otro a su personaje, Fortunata, integrados ambos en "Milagro Español", el calendario que hiciera en lienzo en 1953 por encargo de Mazapanes Toledo. Son breves pero sumamente reveladores de la afinidad y convergencia de su lectura de las novelas galdosianas con la que hiciera María Zambrano. Comienza Gaya imaginando a Galdós paseando por Madrid, como un mendigo que no pide, y al que -textualmente- "la realidad se le iba entregando así, cordialmente, sin violencia, sin conquista, sin estudio" para añadir un poco más adelante, "Galdós no es que mezcle y se pierda en lo real, sino que se solidariza con la realidad sin inmiscuirse en ella...la grandeza de Galdós no la encontramos nunca en la composición ni en el contenido de sus novelas, sino en la relación armoniosa que ha quedado establecida entre él y la Realidad"20. Y, en el texto "Fortunata", Ramón Gaya nos dará la clave de por qué la realidad española ha sido tan reiterada y representativamente formulada como un dualismo, como una contradicción, entre realismo y espiritualidad, entre realismo y mística, "que no es otra cosa que deseo de transfiguración". La clave estaría en que el español y sus encarnaciones artísticas "no buscan nunca el espíritu, la delgadez del espíritu, en un aire favorable, en un clima espiritual, sino que bajan valientemente al fondo de la mina para extraerlo como un carbón" 21 . A un paso estamos ya de toparnos con lo sagrado, no situado en un más allá, no en lo divino trascendente, sino en el fondo de la misma realidad, en lo real como sagrado.

Pero es, sin duda, en las reflexiones sobre la acción creativa en el pensamiento y en la pintura donde las afinidades entre Ramón Gaya y María Zambrano son más hondas y firmes. Por encima de las reservas que Gaya mantuvo respecto a algunos

\footnotetext{
18 Ibídem, p. 136

19 Ibídem, p. 138

20 Gaya, R. "Milagro Español" en Obra Completa (o.c. nota 3), p. 144-5

21 Ibídem, p.145
} 
rasgos de la personalidad de María y del entorno del que se rodeaba en Roma, marquesas e ignorantes, más allá, incluso, de que la encuentre en ocasiones "deshecha, carcomida de resentimientos, venenos ajenos $y$, fantasmas... "22, y de que no comparta la senda órfico-pitagórica transitada por la Zambrano en sus años romanos ("las personas dadas al simbolismo como María cambian la realidad por sus símbolos"23) confiesa reiteradamente que su fascinación por ella deriva de su "talento", de su "talento endemoniado". Ello la salva: "María se salva del señoritismo a causa de la calidad de su talento"'24. Ello la hace merecedora de formar parte de ese restringido y selecto grupo de "mendicantes": José Bergamín, Soledad Martínez, y el propio Ramón Gaya. Al igual que otros muchos que la trataron, como Cioran, Camus, o Lezama Lima, no deja de reconocer en ella ciertos rasgos de Sibila o Pitonisa capaz de desvelar lo que permanece oculto tras lo expresado, de anunciar lo aún no manifiesto.

Pero Ramón Gaya discrepa de que la grandeza y profundidad de María Zambrano tengan su raíz en una inspiración de este tipo al margen del pensamiento. En el luminoso y emotivo artículo que le dedica en 1989, Ramón Gaya subraya que hay que resistirse a la tentación de concebirla bajo aquél prisma. Lo que sucede es que María no se esfuerza en pensar; no se trata de una tarea que se sobreponga a su propio ser, sino que, de forma natural, se funde e integra en él. No cabe un mayor elogio en labios de Gaya pues es bien sabido, para cualquier conocedor de sus ensayos estéticos, que para él, frente al arte artístico, frente a la obra de arte elaborada, técnicamente construida, se yergue la obra creativa, aquella en que, de forma natural, la realidad se entrega a un creador que no pretende captarla ni enseñorearse de ella, sino "salvarla". Al establecer el paralelismo entre el ser-pintura de Velázquez y el ser-pensamiento de María Zambrano, Ramón Gaya nos está desvelando, pese a todas aquellas discrepancias, el sentido profundo de su afinidad, de su encuentro, de su re-conocimiento. "Lo que sucede es que María, nuestra amiga, no se ha... puesto nunca a pensar como tantos-incluso algunas veces el propio Ortega- sino que ha pensado siempre como sin proponérselo, como sin quererlo, como sin...saberlo. Es también la manera de ser, de ser naturaleza que habiamos visto en Nietzsche. Estas buenas y extrañas personas - creadoras naturales de pensamiento, de poesía, de pintura, de música-más que hacer tal o cual cosa, parecen serla sin más... María Zambrano es, pues, una de esas criaturas...creadoras" 25.

No menor es la afinidad en la concepción de la obra pictórica que se muestra en el ensayo que María Zambrano dedicó a Ramón Gaya en 1960, el mismo año en que éste publicara "El sentimiento de la pintura". En este caso, la convergencia de plan-

\footnotetext{
22 Gaya, R. "Diario de un Pintor" 9 febrero 1957, en Obra Completa (o.c. nota 3) p.463

23 Ibídem. 13 junio 1957, p. 468

24 Ibídem, 3 junio 1963, p.512.

25 Gaya, R. (1989) "Maria Zambrano. He pintado ese momento" en Obra Completa (o.c. nota 3) p.873
} 
teamiento llega hasta la práctica literalidad de las expresiones como cuando María Zambrano reitera que la pintura ha surgido del agua, cuando hace referencia al "pasmo", estado previo a la contemplación, como reacción suscitada por las verdaderas obras artísticas, o bien cuando reconoce como condición de posibilidad de éstas la desaparición del yo del artista y la ocultación de su propio oficio de pintor. Pero, al igual que hiciera Gaya respecto del pensar filosófico de María Zambrano, ningún mayor halago cabría tampoco encontrar para la obra de Ramón Gaya que el que su amiga le otorga: el de cumplir con el propio ideal formulado por Ramón en sus ensayos, es decir, el de que se pueda reconocer en sus cuadros la marca de una auténtica creación que transciende la habilidad del artificio artístico y se constituye, por ello, en un acto de revelación de lo que la realidad esconde. "Si detuviésemos, pues, ese instante en que la presencia de algo, de una obra de arte, se nos da y lográramos extraer del todo lo que contiene, en lugar de precipitarnos ávidamente sobre la obra, mirándola como cosa a poseer, aun con la mirada, o como objeto a penetrar, se nos iría dando con simplicidad la revelación que todo lo que se manifiesta contiene. Y si ello sucede siempre así, vemos que sucede aún en mayor grado ante algunas presencias, como ésta de los cuadros de Ramón Gaya. Pues se nos ofrece en una rara forma de presencia: rara por presentarnos una verídica faz de la pintura, de ella, la pintura, tras de la cual queda invisible el pintor"26.

En una reciente conversación con Tomás Segovia, el excelente poeta y gran amigo de Ramón Gaya a través del cual había conocido a María Zambrano en sus años romanos, tuve la oportunidad de preguntarle cuál era, a su juicio, más allá de las anécdotas y de las coincidencias biográficas, y de sus igualmente evidentes diferencias personales y discrepancias teóricas, la raíz, la fuente de la que habría surgido y hecho posible el cúmulo de sus afinidades, y que habría mantenido estrechados sus vínculos de mutua admiración, complicidad y amistad. Su respuesta estuvo cargada de profundidad y lucidez: "Ambos tenían una misma concepción de lo sagrado". En efecto, ambos compartían una similar concepción respecto de la verdad de lo real, de aquello que se deja transparentar tras lo que se nos muestra, y ambos sintonizaban en la actitud que debían mantener su pensamiento y su pintura ante esa realidad: medios pasivos, obedientes y caritativos de su revelación. Cualquier acto creativo es, para María Zambrano y para Ramón Gaya, un acto desvelador del misterio que encierra la realidad, de lo sagrado escondido porque, tanto para uno como para el otro, la realidad es sagrada. Como el propio Tomás Segovia ha dejado escrito en el prólogo de la reciente edición de las Obras Completas de Ramón Gaya: "Es esa revelación de lo sagrado de la realidad, esa fe en lo real salvado pero no condenado - ni traicionado- lo que da su altura a la obra plástica de Ramón Gaya y su fuerza a su obra escrita"27.

26 Zambrano, M. (1960) “La pintura de Ramón Gaya”, en Algunos lugares de la pintura (o.c. nota 8), pp. 209-10

27 Segovia, T. (2010) "Prólogo" en Ramón Gaya, Obra Completa (o.c. nota 3), p.11 
No otra cosa que revelación de la realidad sagrada es lo que perseguía con la palabra María Zambrano y lo que la llevó a buscar una nueva "razón poética" que no la aprisionara con las cadenas del racionalismo, que no la encerrara en la cárcel de los conceptos, que no la congelara y acabara suplantándola, como a la propia vida, con intelectualistas argumentaciones. Una razón poética que fuera, ella misma, creadora y viviente. Y no otra cosa que revelación de la realidad sagrada es lo que perseguía Ramón Gaya al despojar su pintura de todos los estilos, al no dejar de liberarla de todos los andamiajes del arte, al desear que la mano del pintor, la suya, no fuera una mano "sutil ni artificiosa", sino una "mano desnuda, de mendigo"28. El propio Ramón Gaya afirmó explícitamente la existencia de una misma fuente originaria de toda auténtica creación en el pensamiento, en la poesía y en la pintura, y Francisco Brines, otro gran poeta amigo de Ramón Gaya, lo reconocía recientemente al recordar la tesis gayesca de un impulso compartido entre poesía y pintura, en el marco del homenaje que la revista Turia ha dedicado al pintor con ocasión de su centenario: "La posibilidad de sugerir la realidad invisible, que hay en la realidad que vivimos, puede y debe aparecer en toda creación merecedora de tal nombre"29.

Es esa misma capacidad de desvelación de lo sagrado de lo real la que María Zambrano y Ramón Gaya creen poder reconocer en toda auténtica obra creativa, pues en ella no se trata tanto de construir sino de esperar, de obedecer, de someterse "de buen grado a la realidad y a esa herida que la realidad le regala como un don"30. Una capacidad que sólo cabe alcanzar tras una transformación, una purificación personal del propio creador que le posibilita establecer una relación de fusión con la realidad a la que cabe calificar de "mística", pues no se trata de "entenderla, sino de serla". Al fin y al cabo, lo que busca el pintor en la pintura, nos dirá Ramón Gaya, no es "conquistar la realidad, sino sumarse a ella, pertenecerle, ser real, realmente real. Sus obras son como unos bocetos provisionales para un contacto efectivo, para una comunión efectiva, de hombre y realidad" 31 . Es este mismo poder de revelación el que ambos reconocen en los grandes creadores y, por encima de todos, en aquél en el que creen consumado este ser (que no hacer) pintura en el que la realidad se entrega: Velázquez. No es la apariencia de la realidad, sino su Alma lo que el creador nos ofrece en su pintura, pues lo decisivo es lo que lleva encerrado dentro. "Hacia un saber del Alma" es el título que diera María Zambrano al artículo en el que comenzara a mostrar la separación del camino que había emprendido distanciándose de su maestro Ortega y, años más tarde, cuando intenta

\footnotetext{
28 Gaya, R. "Mano vacante" en Obra Completa (o.c. nota 3), p. 636.

29 Citado en Lostalé, J. (2010) "Francisco Brines: Ramón Gaya, nunca se doblegó, fue un ejemplo moral" en Turia, no 95, Junio-Octubre, 2010, p. 24

30 Gaya, R. “El Sentimiento de la Pintura”, en Obra Completa (o.c. nota 3), p.47

31 Ibídem, p.51
} 
justificar la redacción de sus múltiples ensayos sobre la pintura, afirma que "tenía que hablar de lo que veía, para desvelarlo, para desvelar el enigma que encierra la pintura"32. En la misma sintonía, Gaya escribirá que lo que Velázquez, la pintura, nos ofrece no es la realidad del realismo, corpórea, sino lo que en ella se transparenta, lo que lleva dentro, su "centro misterioso"33. Por decirlo con las mismas palabras con las que cierra el soneto que a él le dedicara: "Parece que estuviera bien pintada / la simple realidad indiferente; / pero el Alma está dentro, agazapada"34.

Sin duda, en el estrambote en prosa de este mismo soneto es donde puede encontrarse la mejor clarificación de lo que venimos diciendo sobre el carácter sagrado de la realidad y de la posición que los auténticos creadores, como Velázquez, adoptan ante él. Pues, en rigor a lo que nos referimos cuando aludimos a un Alma agazapada es a un Algo, nos dirá Ramón Gaya, un algo "animado que nos parece ver, o entrever, o entresentir, detrás mismo de la realidad...La realidad - eso lo sabemos todos, lo sentimos todos- es...sagrada; y es sagrada- no divinapor ser portadora, encerradora, escondedora de ese Algo tan ...evidente"35. La realidad será, así pues, sagrada por lo que esconde, como un arca o un sagrario, por ser "escondite de la divinidad"36. Ante ella, la actitud del verdadero artista no será la de idolatrarla, como los realistas, ni tampoco ignorarla, ni desdeñarla, ni vividiseccionarla, como tantos otros, sino recibirla, tenerla presente y dejarla estar con amoroso desapego.

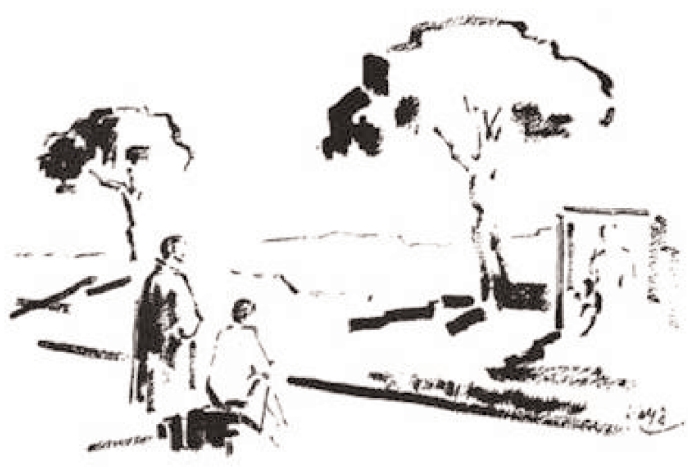

Para finalizar esta revisión de las afinidades entre María Zambrano y Ramón Gaya pensé, en un primer momento, ejemplificar aquella convergencia de sus miradas, que se había iniciado en las originarias visiones de un níspero y en un limone-

\footnotetext{
32 Zambrano, M. "Introducción” en Algunos Lugares de la Pintura (o.c. nota 8), p.12

33 Gaya, R. "Velázquez, pájaro solitario", en Obra Completa (o.c. nota 3), p. 118

34 Gaya, R. "Velázquez. Soneto con estrambote en prosa", en Obra Completa (o.c. nota 3), p. 631

35 Ibídem, p.632

36 Ibídem, p.633
} 
ro, analizando el dibujo que Ramón hiciera en unos de sus paseos compartidos por la Vía Appia, y en el que representa a ambos de espaldas en ese momento en que él mismo declara que vio a María más "plena" 37: ella, sentada, contemplando la estela funeraria romana con la figura borrosa de su iniciático enamorado; él, de pie, contemplando también pero, al menos éste aficionado así lo siente, pasmado no ante la pétrea ruina recargada de simbolismo, sino ante la forma viva de la copa del pino romano que crecía a su lado ${ }^{38}$. Miran en la misma dirección, aunque, a mi parecer, no contemplan lo mismo.

Sin embargo, de acuerdo con el hilo narrativo que venimos siguiendo y que nos ha llevado a centrarnos en la pintura como medio revelador de lo sagrado de la realidad, me ha parecido más significativo y relevante traer a colación la convergente y afín mirada que ambos, María Zambrano y Ramón Gaya, dirigieron sobre una de las obras en la que Velázquez habría alcanzado con mayor profundidad su creadora capacidad de desvelación: "El Niño de Vallecas".

La fascinación de Ramón Gaya por Velázquez se remonta, como es bien sabido, a su juventud al reencontrarse con esa "roca española" que constituye el Museo del Prado tras la decepción que le producen las vanguardias parísinas. El retrato que el pintor sevillano hiciera del enano bufón, Francisco Lezcano, o el Vizcaíno, no aparece mencionado en los escritos de Ramón Gaya hasta 1951. Pero a partir del ensayo "El Silencio del Arte", que integrará en "El Sentimiento de la Pintura", el "Niño de Vallecas" pasa a ocupar un lugar central en su análisis de la pintura de Velázquez. En él se mostraría, de forma paradigmática, cuál es la actitud ante la realidad que se corresponde con su genialidad creadora. El "realismo" velazqueño se nos revela con toda claridad en esta obra -nos dirá Gaya- como una auténtica mística. "Ahí es donde está la clave de su actitud, casi sagrada, ante el Niño de Vallecas: son dos santidades frente a frente, dos iguales, pero no son dos iguales exteriores, por su calidad de criados -como se ha dicho-, sino dos iguales de alma, de tontería, de pureza". El interés de Velázquez por los enanos bufones no reside en descifrar su psicología ni en denunciar el entramado social de la Corte de los Austrias, como una interpretación superficial ha tendido a subrayar. Lo que su pincel deja aparecer es la propia realidad desnuda e inocente. "Delante de estos bufo-

\footnotetext{
37 Gaya, R. "Maria Zambrano (He pintado ese momento)" en Obras Completas (o.c. nota 3) p. 874 38 Ya no existe el pino que Ramón Gaya esbozara en su viñeta. La estela funeraria tiene hoy tras de sí la alambrada de un recinto militar. Representa a un joven desnudo con una capa echada hacia atrás. A ella dedicó en 1988 Maria Zambrano uno de sus más bellos textos de recuerdos romanos "El desnudo iniciático" (Cfr. Zambrano, M. Las palabras del regreso, Madrid, Cátedra, 2009, pp. 167-169) aunque la referencia que aporta de su localización es errónea: en lugar de cerca de un inexistente cruce entre la Vía Appia y la Vía Latina, la estela se encuentra a unos cien metros del no 258 de la Vía Appia Antica, en el borde derecho de la propia Vía Appia, y a unos 500 metros del cruce de ésta con la salida hacia Vía Metelli y Vía Caetana.
} 
nes idiotas, tan patéticos para unos ojos menores, Velázquez comprende que está delante de Dios. Lo verdaderamente hermoso, oscuro de esos cuadros es que son como altares, altares donde la realidad ha sido salvada"39.

Años más tarde, cuando Gaya escriba su más brillante homenaje escrito -no pintado- a Velázquez, aquél místico "pájaro solitario", presentará "El Niño de Vallecas" como la consumación de esa actitud que renuncia a todo actuar para limitarse a estar, como el lienzo donde la propia pintura ha sido sobrepasada, y donde la pasividad y distanciamiento del artista creador posibilita que lo sagrado de lo real se haga presente por sí sólo. "Todos los retratos velazqueños vienen a ser como altares, pero El niño de Vallecas es el altar mayor de su obra, el escalón supremo de su obra desde donde poder saltar, pasar al otro lado de todo, más allá de todo...Ante El niño de Vallecas Velázquez no actúa en absoluto, no se compadece, no se lamenta, no sufre ni se complace, no se burla o ensaña, ya que ha logrado, por fin, su más perfecta pasividad creadora; a El niño de Vallecas Velázquez lo deja intacto, vivir, venir a vivir, a estarse entero y verdadero en su gloria de ser vivo, dueño en redondo de su ser central" 40.

Algunos prestigiosos intelectuales españoles, como Ortega y Eugenio D’Ors, apenas prestaron atención en sus ensayos sobre Velázquez y el Prado a este cuadro y no mostraron una especial sensibilidad artística ante la figura del bufón. Pero su posición no fue generalizada. La expresividad, el sentimiento y el misterio que emanan de "El Niño de Vallecas" impresionaron con fuerza a otros muchos críticos de arte y poetas españoles contemporáneos de Zambrano y de Gaya, como es el caso de León Felipe que le dedicó un poema, recogido en "Versos y Oraciones del Caminante", en el que pone en boca de Don Quijote la siguiente admonición. "De aqui no se va nadie / Mientras esta cabeza rota / Del Niño de Vallecas exista, / De aquí no se va nadie. Nadiel Ni el místico ni el suicida. Antes hay que deshacer este entuerto / Antes hay que resolver este enigma". ${ }^{41}$ La mayor parte de ellos se sintieron subyugados por la caritativa forma como Velázquez presenta al enano bufón, y por el misterio que parecen encerrar la luz que emana de su rostro y la entrecortada sonrisa que dirige al espectador.

También María Zambrano profundizó en el sentido de este enigma y creyó poder desvelar la verdad que se transparentaba tras la deforme imagen del "Niño de Vallecas". Lo primero que cabe decir al respecto es que, a su juicio, en esta obra vendría a plasmarse, de forma ejemplar, la capacidad de toda auténtica creación humana de desvelar la verdad de la realidad, de mostrar su carácter sagrado, en la que habíamos enraizado la radical afinidad entre Gaya y Zambrano sobre el senti-

\footnotetext{
39 Gaya, R. "El silencio del arte" en Obra Completa (o.c. nota 3), p. 74

40 Gaya, R. "Velázquez, pájaro solitario" en Ibídem, pp. 120-21

${ }^{41}$ León Felipe, "Pie para El niño de Vallecas de Velázquez", en Versos y oraciones del caminante, Madrid, Visor, 1981, p. 79
} 
do y razón de ser del arte. Al rememorar en 1955 una visita realizada en su juventud al Museo del Prado con otros compañeros, María Zambrano escribe " $Y$ se dieron cuenta de que no miraban la pintura como tal, sino lo que en ella habia, lo revelado por su magia invisible, y no es que fuera real ¿realista Velázquez?"42.

En "El Niño de Vallecas" vendría a cumplirse de manera ejemplar la verdad del aserto de María Zambrano que, con idénticas palabras, pudiera haber sido escrito también por Ramón Gaya: "el arte que se ve como arte es distinto que el arte que hace ver" 43 . En el prólogo que escribiera diez años más tarde para la recopilación de ensayos que llevaba por título "España, Sueño y Verdad", al intentar justificar por qué dos de ellos están dedicados a un personaje de la vida, el Idiota, y no a un personaje meramente literario, nos confesará su atracción por la imagen que de él ofreciera Velázquez al retratar a "El Niño de Vallecas", "una de esas imágenes enigmáticas y, al modo humano, sagradas, depositarias de una misteriosa cuanto humilde verdad. Es decir, de una verdad misteriosa envuelta en una opaca figura que todos creen saber a qué corresponde, hasta que un día alguien se siente herido por la luz que emana mansamente del rostro de ese idiota" 44 .

A fuer de sincero, sin embargo, estas afinidades entre las miradas estéticas de María Zambrano y Ramón Gaya tan sólo reflejan una parte de la verdad, de lo contrario, no se haría comprensible cómo, para la pensadora, quien más altas cotas de mostración de lo sagrado alcanzó es Zurbarán, mientras que para el pintor nadie como Velázquez ha ido más allá de la pintura en la desvelación mística de la verdad de lo real. Por ceñirnos al caso que venimos analizando, resulta evidente la diferencia en la motivación que prevalece en la mirada de cada uno: en el caso de Gaya, como vimos, el interés por la posición ético-religiosa del pintor ante el objeto de su "pasividad creadora", y, en el caso de Zambrano, la pasión por descubrir el significado oculto de una imagen que es concebida, esencialmente, como símbolo. Filosofía y Pintura podían converger en su camino y compartir afinidades, pero seguían siendo actividades diferentes y buscaban objetivos distintos. Bien lo supo reconocer Ramón Gaya en la anotación ya citada de su Diario de un Pintor que merece ser transcrita aquí de forma completa: "las personas dadas al simbolismo (como María) cambian la realidad por sus símbolos en vez de ver por transparencia los símbolos que hay en la realidad, que forman parte de ella pero no la sustituyen "45. Esta deriva de María Zambrano se hace especialmente notable a partir de su estancia en Roma y de la progresiva influencia que sobre ella ejercieron personas como Ellemire Zola, Cristina Campo y Elena Croce. Son justamente los años, en que se incrementará su interés por la pintura, que a partir de entonces ocupará un

\footnotetext{
42 Zambrano, M. "Una visita al Museo del Prado", en Algunos lugares de la pintura, (o.c. nota 8) p. 48

43 Zambrano, M. ibídem

44 Zambrano, M. "Prólogo", en España, sueño y verdad, Madrid, Edhasa, 1965, p.12

45 Gaya, R. Diario de un pintor 13 junio 1957, en Obra Completa ( o.c. nota 3) p. 468
} 
lugar preferente en su reflexión filosófica, y en los que se inscriben gran parte de sus ensayos sobre obras pictóricas.

No ha de extrañar, por tanto, que en las referencias que dedica a "El Niño de Vallecas", el enfoque predominante no sea el de su "verdad pictórica", sino el de su "verdad simbólica". La propia función de la pintura como arte parece diluirse en la de un figurativo medio de expresión, en la de una palabra expresada en imágenes. Sus figuras han regido "como símbolos, como enigmas a descifrar, como heraldos, pues que todo ello quiere decir que han sido vistos y sentidos, tratados como palabras" 46 . En efecto, "El Niño de Vallecas", a los ojos de María Zambrano, es, ante todo, una imagen del "idiota" y de lo que éste simboliza. Tanto en las referencias que le dedica en "Un capítulo de la palabra: El idiota" (1962) como en "Apuntes sobre el lenguaje sagrado y las artes" (1971), se trata de indagar en el enigma que esconde ese ser humano "desposeído de la palabra". Más allá de la belleza de las descripciones que María Zambrano lleva a cabo sobre el modo del ser-en-el-mundo del idiota, de su vagar sin meta ni orden, de su ser extraño para todos, testigo de un remoto saber sumido en el silencio, necesario resulta reconocer que no es en la pintura en lo que fija su mirada sino, a lo más, como imagen que lanza a nuestro pensamiento tras el misterio que encierra.

Por ello, resulta congruente la importancia que María concede, en sus reflexiones, a lo que las manos entreabiertas de "El Niño de Vallecas" dejan entrever: en lugar de la mayoritaria opinión de los expertos en Velázquez (incluido el propio Gaya), es decir, unos naipes con los que el bufón se entretiene y juega, Zambrano vislumbra un papel en el que estaría escrita una única palabra: " $Y$ un día ya no dirá nada más. Se quedará casi desvanecido con las manos juntas y entreabiertas, como si en su hueco llevase la palabra que ha guardado y que ofrece sin leer" 47 . No es el único lugar en el que las cadenas simbólicas llevarán a María Zambrano lejos de la realidad pictórica de lo manifestado en el cuadro. Por tres veces al menos, creerá poder atribuir a "El Niño de Vallecas" la condición de exiliado de Palacio por el hecho de que Velázquez lo retrate en plena naturaleza, en lugar de la corte, con la sierra madrileña al fondo, al igual que hiciera con su dueño, el príncipe Baltasar Carlos, sin atender a que el cuadro fuera pintado para el pabellón de caza "Torre de la Parada" en el monte de El Pardo y que, por ello también Francisco Lezcano, el Vizcaíno, aparezca vestido con ropas verdes de cazador. Del mismo modo, el árbol sobre el que apoya su espalda, se transforma ante la mirada de María Zambrano nada menos que en "El árbol de la Vida" como lugar apropiado para acoger al "ino-

\footnotetext{
46 Zambrano, M. “Apuntes sobre el lenguaje sagrado y las artes”, en Algunos lugares de la pintura. (o.c. nota 8) p. 114.

47 Zambrano, M. "Un capítulo de la palabra: El Idiota", en España, Sueño y Verdad, (o.c. nota 43), p. 235. Cfr. también, "Apuntes sobre el lenguaje sagrado y las artes", en Algunos lugares de la pintura, (o.c. nota 8 ), p. 118
} 
cente" pues no otra cosa simboliza "El Niño de Vallecas" que se encontraría al margen del "árbol de la ciencia del bien y del mal".

Más próxima hacia la verdad que el arte en sí mismo, y no como mero medio de figuración simbólica, se orienta a transmitir se encuentra el esbozo que del mismo "Niño de Vallecas" Ramón Gaya pintara, sin árbol, ni sierra nevada, ni papel ni naipes, casi tan sólo con su mirada y su entrecortada sonrisa. Es decir, lo esencial, la verdad pictórica, sólo aquello que queda después de que todo lo demás haya sido borrado por la mano desnuda del pintor.

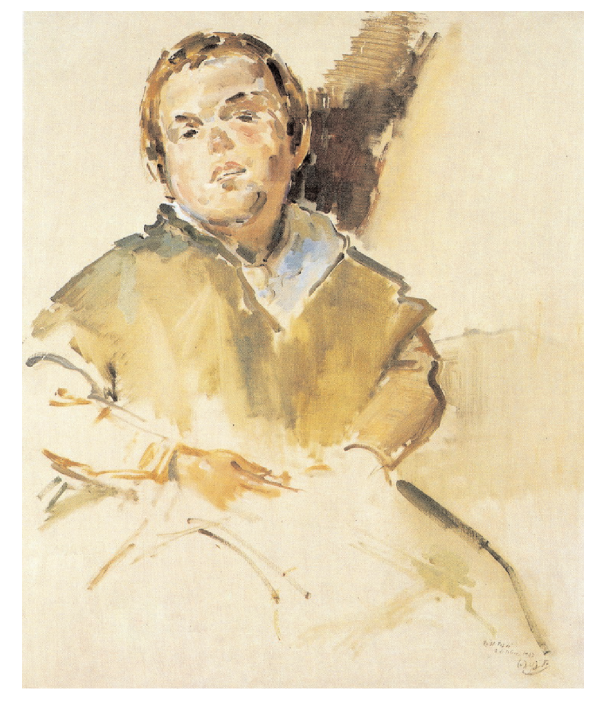

Todo esto sea dicho, con los aciertos y los errores que pueda encerrar, como muestra de agradecimiento, tanto a Ramón Gaya como a María Zambrano, por haber enriquecido con sus afinidades y discrepancias mi propia mirada sobre tantas cosas y, entre ellas, por haberme ayudado a sospechar que lo que intenta darnos a entender con la suya "El Niño de Vallecas" es (Gaya dixit) algo difícil y excesivo para nosotros, y que acaso lo haga "lleno de pena y de vergüenza por saberse en la verdad, mientras nosotros seguimos aquí, en la realidad únicamente"48

48 Gaya, R. "Velázquez, pájaro solitario", (o.c. nota 32), p. 122 